\title{
Electrolytic cell engineering and device optimization for electrosynthesis of e-biofuels via co-valorisation of bio-feedstocks and captured $\mathrm{CO}_{2}$
}

\author{
Faraz Montazersadgh ${ }^{1}$, Hao Zhang ${ }^{1}$, Anas Alkayal ${ }^{2}$, Benjamin Buckley ${ }^{2}$, Ben W. Kolosz ${ }^{3}$, Bing $\mathrm{Xu}^{4}$, \\ Jin Xuan (囚) ${ }^{1}$ \\ 1 Department of Chemical Engineering, Loughborough University, Loughborough, LE11 3TU, UK \\ 2 Department of Chemistry, Loughborough University, Loughborough, LE11 3TU, UK \\ 3 Department of Chemical Engineering, Worcester Polytechnic Institute, Worcester, MA 01609-2280, USA \\ 4 Department of Accountancy, Economics and Finance, Heriot-Watt University, Edinburgh, EH14 4AS, UK
}

(C) The Author(s) 2020. This article is published with open access at link.springer.com and journal.hep.com.cn 2020

\begin{abstract}
Utilizing $\mathrm{CO}_{2}$ in an electro-chemical process and synthesizing value-added chemicals are amongst the few viable and scalable pathways in carbon capture and utilization technologies. $\mathrm{CO}_{2}$ electro-reduction is also counted as one of the main options entailing less fossil fuel consumption and as a future electrical energy storage strategy. The current study aims at developing a new electrochemical platform to produce low-carbon e-biofuel through multifunctional electrosynthesis and integrated covalorisation of biomass feedstocks with captured $\mathrm{CO}_{2}$. In this approach, $\mathrm{CO}_{2}$ is reduced at the cathode to produce drop-in fuels (e.g., methanol) while value-added chemicals (e.g., selective oxidation of alcohols, aldehydes, carboxylic acids and amines/amides) are produced at the anode. In this work, a numerical model of a continuous-flow design considering various anodic and cathodic reactions was built to determine the most techno-economically feasible configurations from the aspects of energy efficiency, environment impact and economical values. The reactor design was then optimized via parametric analysis.
\end{abstract}

Keywords electrosynthesis, e-biofuels, $\mathrm{CO}_{2}$ utilization, computational model

\section{Introduction}

Research on electrochemical reduction of $\mathrm{CO}_{2}$ has drawn intensive attention in recent years for the purpose of reducing the $\mathrm{CO}_{2}$ emission, as well as energy storage of

Received January 31, 2020; accepted April 6, 2020

E-mail: j.xuan@lboro.ac.uk renewable electricity generated from solar and wind energy [1]. $\mathrm{CO}_{2}$ electro-reduction technology is at its infancy stages especially from an industrial point of view. The main issue lies in its economic viability due to the high energy consumption and relatively low energy conversion efficiency. Moreover, long-term economic impacts and environmental issues are counted amongst the issues of this approach [2]. The energy and cost analyses based on techno-economic and environmental evaluation indicates that electrochemical systems can be sustainable only when electrolyser technology becomes more mature [3]. In this regard, formic acid electrosynthesis using $\mathrm{CO}_{2}$ as raw material is one of the most commonly explored kinetics due to its simple charge transfer pathways and fast kinetics comparing with other conversion reactions [4]. The recent studies show exciting results of efficient formic acid electrochemical synthesis from $\mathrm{CO}_{2}$ on low cost catalyst [5]. The selectivity of the formation of the formic acid with respect to the total $\mathrm{CO}_{2}$ reduced product is around $95.73 \%$. The performance can be further enhanced by electrode material enhancement and membrane improvement [6,7]. While solid oxide electrolysers show a promising alternative trend in $\mathrm{CO}_{2}$ utilisation, due to high operational temperature, system optimization is still under investigation and requires further improvement [8-12].

As the other half electrochemical reaction associating with $\mathrm{CO}_{2}$ reduction, oxygen evolution reaction (OER) at anode is another source contributing major part of energy loss within the electrolyzer. About $70 \%$ of the whole energy loss is caused by OER [13]. Moreover, in order to minimize the voltage loss of OER, catalysts based on noble metals are generally applied [14]. Unfortunately, although considerable energy along with the high cost catalyst is consumed, the byproduct $\left(\mathrm{O}_{2}\right)$ generated from anode 
brings little value.

Using biofuels or organic wastes as resources to synthesize high value-added chemicals under controllable electro oxidization is regarded as a promising and viable way to promote the economic viability of electrochemical approach for $\mathrm{CO}_{2}$ mitigation [15]. However, this approach, known as 'e-biofuel' is still at its initial stage. The feasibility and technical potential of coupling it with $\mathrm{CO}_{2}$ electrochemical reduction is less explored from an industrial point of view.

In this work, a numerical model of a continuous-flow design considering various anodic and cathodic reactions was built to investigate the products generation from the aspects of energy efficiency, environment impact and economical values. Numerical analyses on device optimization and device engineering in different economic and industrial scenarios were carried out as well. This study provides a comprehensive understanding on simultaneous electrochemical synthesis of high add-valued chemicals and $\mathrm{CO}_{2}$ reduction.

\section{Experimental}

\subsection{Problem description}

The first step in designing an electrolytic cell is deciding the reaction kinetics which is to take place at each electrode. The chosen kinetics greatly affects the reactor geometry, inlet liquid and gas flow velocities and electrode catalyst material. To identify the half-cell reactions with the desired performance properties, at least one reaction was chosen from each potential cathode and anode halfcell group (e.g., carboxylic acids, alcohols, aldehydes, etc.). Recent progress involving $\mathrm{CO}_{2}$ electroreduction and biomass oxidation for fuel production were also extracted from literature and included in the reaction list. Herein, 20 anodic and 10 cathodic half-cell reactions are listed in Tables 1-3. Water is assumed to be the solvent for watersoluble reactants while dimethylformamide (DMF) is used where an organic solvent is required. The model schematic for e-biofuel reactor is shown in Fig. 1.

\subsection{Computational model}

The maximum Reynold's number at the centre of the liquid channel is below 0.4. This leads to a laminar flow system that can be described by Naiver-Stocks and continuity equations:

$$
\begin{gathered}
\rho(\boldsymbol{u} . \nabla) \boldsymbol{u}=-\nabla \cdot\left(p \boldsymbol{I}+\mu\left(\nabla \boldsymbol{u}+\left(\nabla \boldsymbol{u}^{\mathrm{T}}\right)\right),\right. \\
\rho \nabla \cdot \boldsymbol{u}=0,
\end{gathered}
$$

where $\rho$ is the liquid density, $\boldsymbol{u}$ is velocity, $p$ refers to pressure, and $\boldsymbol{I}$ denotes the unit matrix in the proposed spatial dimension. The boundaries at the walls and the electrodes were assumed to be non-slip. The inlet gas was assumed to be at $20^{\circ} \mathrm{C}$ and $1.013 \times 10^{5} \mathrm{~Pa}$ with the gas completely dissolving in the liquid phase. The gaseous byproducts are assumed to diffuse through the anode completely, hence the bubble mechanics are neglected in the computational fluid dynamics (CFD) model.

The species mass balance is described by Eq. (3):

$$
\nabla \cdot\left(\rho \boldsymbol{u} X_{i}\right)-\nabla \cdot\left(\rho D_{i} \nabla X_{i}\right)= \pm \frac{M_{i} A}{n_{i} F V}\left|j_{i}\right|,
$$

where $A$ is the area, $V$ is the volume of the cell, $F$ is the Faraday constant, $n_{i}$ denotes the number of transferred electrons, $X_{i}$ is the mass fraction, $D_{i}$ is the diffusivity, $M_{i}$ is the molar weight and $j_{i}$ is the partial current density for species $i$. Constant species mass fraction is assumed at the inlet while non-flux boundaries are set at the electrodes and zero diffusive flux at the outlet.

Charge conservation is accounted for by Eq. (4):

$$
\sigma \nabla^{2} \varphi=\frac{A}{V} \sum j_{i}
$$

where $\sigma$ is the electric conductivity and $\varphi$ refers to the electric potential. A constant potential was assumed at the

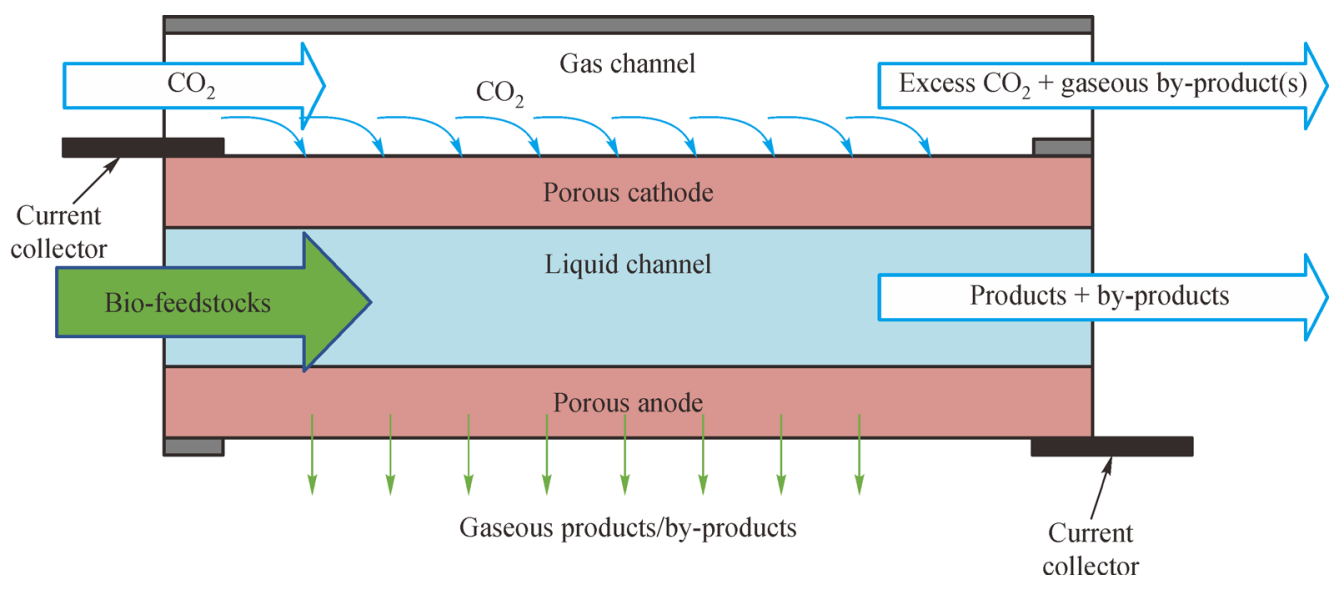

Fig. 1 Model schematic for e-biofuel reactor. 
electrodes as a boundary condition for charge conservation equation.

The resulting system of equations combined with the electrode kinetics described in 2.3 was solved using Galerkin Finite Element Method in COMSOL Multiphysics $^{\circledR}$ [35]. A 2D geometry was created and the computational domain was described using 7692 tetrahedral mesh elements. The number of degrees of freedom solved was 36876 , and the computational time was approximately $2 \mathrm{~min}$ for each case on a PC with quadcore Intel core i-7 CPU at $2.8 \mathrm{GHz}$ and $16 \mathrm{~GB}$ RAM.

\subsection{Electrode kinetics}

Electrochemical reactions are assumed to occur at the electrode surfaces as listed in Tables 1-3. In cases where water is the solvent, the hydrogen evolution reaction (HER) is a side reaction at the cathode which can be shown as:

$$
2 \mathrm{H}_{2} \mathrm{O}+2 \mathrm{e}^{-} \rightarrow \mathrm{H}_{2}+2 \mathrm{OH}^{-}
$$

At the anode, the oxidation reaction can be shown as:

$$
2 \mathrm{OH}^{-} \rightarrow 0.5 \mathrm{O}_{2}+\mathrm{H}_{2} \mathrm{O}+2 \mathrm{e}^{-}
$$

Electrode overpotential at each electrode is defined by:

$$
\eta=E-E^{0},
$$

where $\eta$ is the electrode overpotential, $E$ is the electrode potential and $E^{0}$ is the equilibrium potential of each partial reaction. This value can then be calculated by using Tafel law:

$$
\eta=\frac{R T}{\alpha z F} \ln \left(\frac{j}{j_{0}}\right),
$$

where $R$ is universal gas constant, $T$ is the temperature, $z$ is the electron transfer number, $j$ refers to the electrode current density, $j_{0}$ is the exchange current density and $\alpha$ is the charge transfer coefficient. For $\mathrm{CO}_{2}$ reduction half-cell, a mass transfer constraint is imposed and Eq. (8) is rewritten as [36]:

$$
\eta_{\mathrm{CO}_{2}}=\frac{R T}{\alpha_{\mathrm{CO}_{2}} z F} \ln \left(\frac{j}{j_{0}} \cdot \frac{C_{0, \mathrm{CO}_{2}}}{C_{\mathrm{CO}_{2}}}\right),
$$

\begin{tabular}{|c|c|c|c|}
\hline Reaction No. & Reaction & Conditions & Ref. \\
\hline$\overline{1}$ & $4 \mathrm{OH}^{-} \rightarrow \mathrm{O}_{2}+2 \mathrm{H}_{2} \mathrm{O}+4 \mathrm{e}^{-}$ & $\mathrm{Pt}, 1 \mathrm{~mol} / \mathrm{L}, 6{ }^{\circ} \mathrm{C} \pm 1{ }^{\circ} \mathrm{C}$ & {$[16]$} \\
\hline 2 & $\mathrm{HCOO}^{-} \rightarrow \mathrm{CO}_{2}+\mathrm{H}^{+}+2 \mathrm{e}^{-}$ & $\mathrm{Pd}, 1 \mathrm{~mol} / \mathrm{L}, 6{ }^{\circ} \mathrm{C} \pm 1{ }^{\circ} \mathrm{C}$ & {$[16]$} \\
\hline 3 & $2 \mathrm{CH}_{3} \mathrm{COO}^{-} \rightarrow \mathrm{CH}_{3} \mathrm{CH}_{3}+2 \mathrm{CO}_{2}+2 \mathrm{e}^{-}$ & $1 \mathrm{~mol} / \mathrm{L}, \mathrm{pH}>4,348 \mathrm{~K}$ & {$[17,18]$} \\
\hline 4 & 2 Propionate $^{-} \rightarrow \mathrm{C}_{4} \mathrm{H}_{10}+2 \mathrm{CO}_{2}+2 \mathrm{e}^{-}$ & $\mathrm{Pt}, 1 \mathrm{~mol} / \mathrm{L}, \mathrm{pH}=7$ & {$[17,19]$} \\
\hline 5 & Methanol $+2 \mathrm{H}_{2} \mathrm{O} \rightarrow \mathrm{HCO}_{3}^{-}+7 \mathrm{H}^{+}+6 \mathrm{e}^{-}$ & $\mathrm{pH}=7$ & [19] \\
\hline 6 & Ethanol $+5 \mathrm{H}_{2} \mathrm{O} \rightarrow 2 \mathrm{HCO}_{3}^{-}+14 \mathrm{H}^{+}+12 \mathrm{e}^{-}$ & $\mathrm{pH}=7$ & [19] \\
\hline 7 & $\mathrm{C}_{3} \mathrm{H}_{8} \mathrm{O}_{3}+8 \mathrm{OH}^{-} \rightarrow 3 \mathrm{HCOOH}+5 \mathrm{H}_{2} \mathrm{O}+8 \mathrm{e}^{-}$ & $298 \mathrm{~K}, 1$ bar & [20] \\
\hline 8 & $\mathrm{C}_{3} \mathrm{H}_{8} \mathrm{O}_{3}+2 \mathrm{OH}^{-} \rightarrow \mathrm{C}_{3} \mathrm{H}_{6} \mathrm{O}_{3}+2 \mathrm{H}_{2} \mathrm{O}+2 \mathrm{e}^{-}$ & $298 \mathrm{~K}, 1$ bar & [20] \\
\hline 9 & $\mathrm{Ph}-\mathrm{CH}-\mathrm{OH}-\mathrm{CH}_{3} \rightarrow \mathrm{Ph}-\mathrm{C}=\mathrm{O}-\mathrm{CH}_{3}+2 \mathrm{e}^{-}+2 \mathrm{H}^{+}$ & $\begin{array}{c}0.2 \mathrm{mmol} / \mathrm{L} \mathrm{TEMPO}, 0.5 \mathrm{~mol} / \mathrm{L} \\
\mathrm{NAHCO}_{3}\end{array}$ & [21] \\
\hline 10 & FDCA & $\begin{array}{c}\mathrm{Pt}, 0.3 \mathrm{~mol} / \mathrm{L} \mathrm{NaClO} \mathrm{H}_{4}, \mathrm{pH}=10 \text { to } \\
13,20^{\circ} \mathrm{C}\end{array}$ & {$[22,23]$} \\
\hline 11 & FDCA & $\mathrm{pH}<7.0, \mathrm{NiFe} \mathrm{LDH}$ & [24] \\
\hline 12 & $\mathrm{NH}_{2}$ & $\mathrm{AgO}, \mathrm{NaOH}$ & [25] \\
\hline 13 & $\mathrm{C}_{6} \mathrm{H}_{12} \mathrm{O}_{6}+2 \mathrm{OH} \rightarrow \mathrm{C}_{6} \mathrm{H}_{12} \mathrm{O}_{7}+\mathrm{H}_{2} \mathrm{O}+2 \mathrm{e}^{-}$ & $298 \mathrm{~K}, 1 \mathrm{bar}$ & [20] \\
\hline 14 & $\mathrm{CH}_{4}+2 \mathrm{OH} \rightarrow \mathrm{CH}_{3} \mathrm{OH}+\mathrm{H}_{2} \mathrm{O}+2 \mathrm{e}^{-}$ & $298 \mathrm{~K}, 1$ bar & [20] \\
\hline 15 & $\mathrm{Ph}$ & $\mathrm{KI}, \mathrm{H}_{2} \mathrm{O}, t-\mathrm{BuOH}$ & [26] \\
\hline
\end{tabular}

where $C_{\mathrm{CO}_{2}}$ is the local carbon dioxide concentration.

To incorporate the half-cell reactions in the model, a few factors need to be specified. The first factor is standard free

Table 1 Anodic reactions with water as solvent 
Table 2 Anodic reactions with DMF as solvent ${ }^{\text {a) }}$

Reaction No.

a) The electrolyte conductivity was acquired from [27], physical properties from [28].

Table 3 Cathodic reactions with organic and inorganic solvent

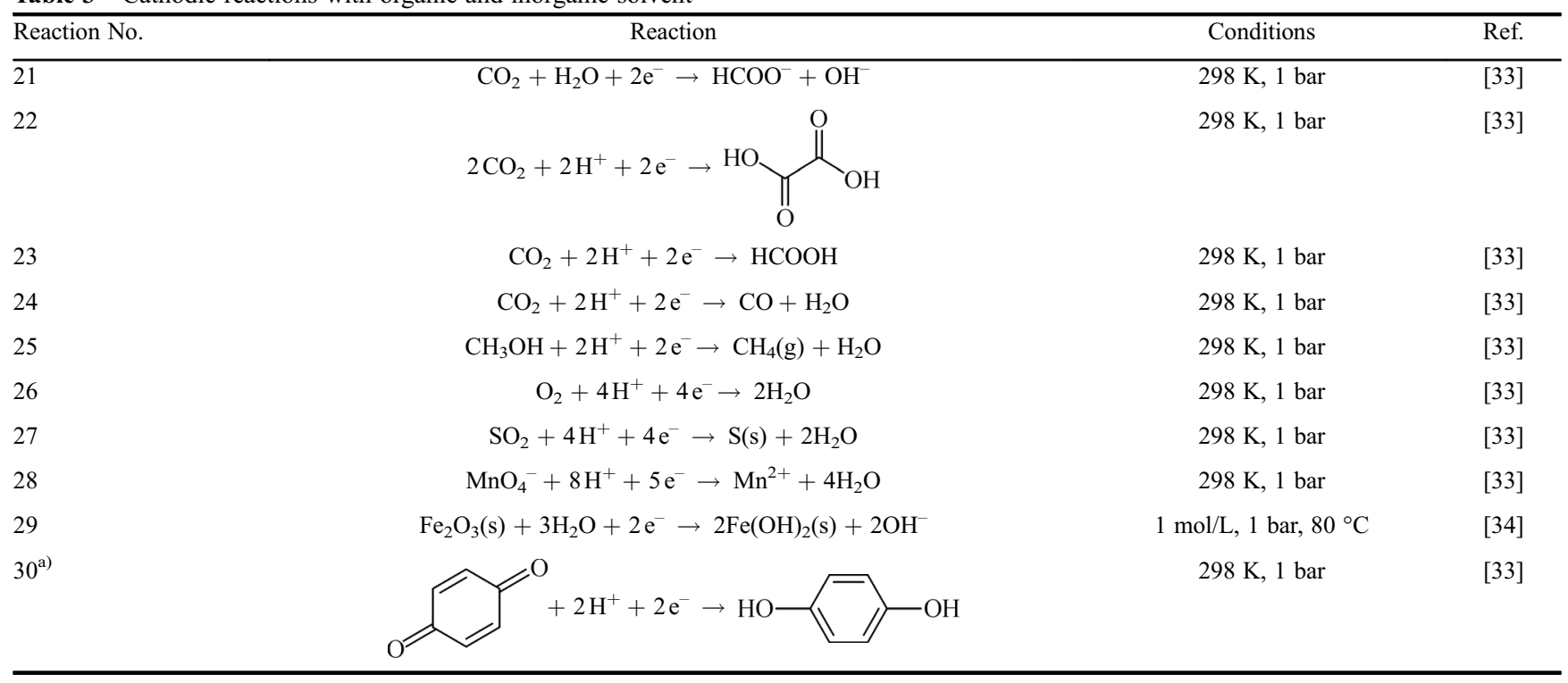

a) DMF as solvent.

Gibbs energy of formation for each reactant and product species. This is to determine cell energy performance (e.g., energy efficiency and current efficiency) and to estimate cell equilibrium potential when experimental values are not available in the literature. Standard Gibbs free energy of formation was extracted from [37-39] and estimated by Joback method [40] in case of more structurally complicated organic compounds. Cell equilibrium potential can be estimated by:

$$
E_{\text {cell }}=-\Delta G / z F \text {. }
$$

With the results being mostly accurate (error bellow 4\%) when compared with experimental observations.

Another important factor is the cell exchange current density used in Eqs. (8) and (9). This value was estimated by scaling cell exchange current density from available experimental observations through the following equation [41]: 


$$
\frac{j_{0, x}}{j_{0,1}}=\frac{z_{x} \exp \left(\frac{\Delta G_{x}}{R T}\right)}{z_{1} \exp \left(\frac{\Delta G_{1}}{R T}\right)}
$$

where $x$ indicates the exchange current density to be scaled and 1 denotes the known exchange current density.

\subsection{Model validation}

The CFD model results are compared with experimental data as shown in Fig. 2. The computational model velocity field shows a good correlation with experimental data extracted from [42]. To further validate the computational model, electrode potential vs. current density is plotted for $\mathrm{pH}$ of 10 in a case where $\mathrm{CO}_{2}$ is used at the cathode (reaction 21 in Table 3) and compared with experimental results from reference [43] as shown in Fig. 3. The input parameters used are listed in Table 4.

\section{Results and discussion}

\subsection{Mass transfer}

Mass transfer throughout the cell plays a key role in determination of cell efficiency and overall performance. For the case study explained in section $2.4, \mathrm{CO}_{2}$ mass fraction decreases across the cathode. The $\mathrm{CO}_{2}$ removal rate is only $24.4 \%$ in this case, which implies there is a great room for improvement by replacing the half-cell reaction and improving cell design. Since HER in this case is regarded as a parasitic reaction, which decreases the cell energy efficiency, the mass fraction of hydrogen as high as 0.7 at the outlet is another indication of cell poor performance. Formic acid is formed in the liquid phase across the cathode accumulating towards the outlet of the electrolytic cell. While $\mathrm{OH}^{-}$is produced at the cathode according to Eq. (5), it is consumed at the anode according to Eq. (6), affecting the local $\mathrm{pH}$ profile in the system. The average $\mathrm{pH}$ may not show significant variation when measured experimentally at the cell outlet, however, the local $\mathrm{pH}$ becomes particularly important where the electrode surface and catalyst performance is influenced by the local $\mathrm{pH}$ of the system.

Each cell kinetic scheme imposes specific limitations in terms of mass transfer in the system. Understanding the bottleneck in each case provides an insight to the overall contribution of each electrode where potentially removing the limitation can improve the cell efficiency. Table 5 shows the limiting factor in each reaction scheme. The limiting factor was characterised by calculating the availability of each reactant at the electrode surface towards the outlet of the cell. Once the reactant concentration drops below a threshold on the surface of one electrode, it is marked as the mass transfer limiting

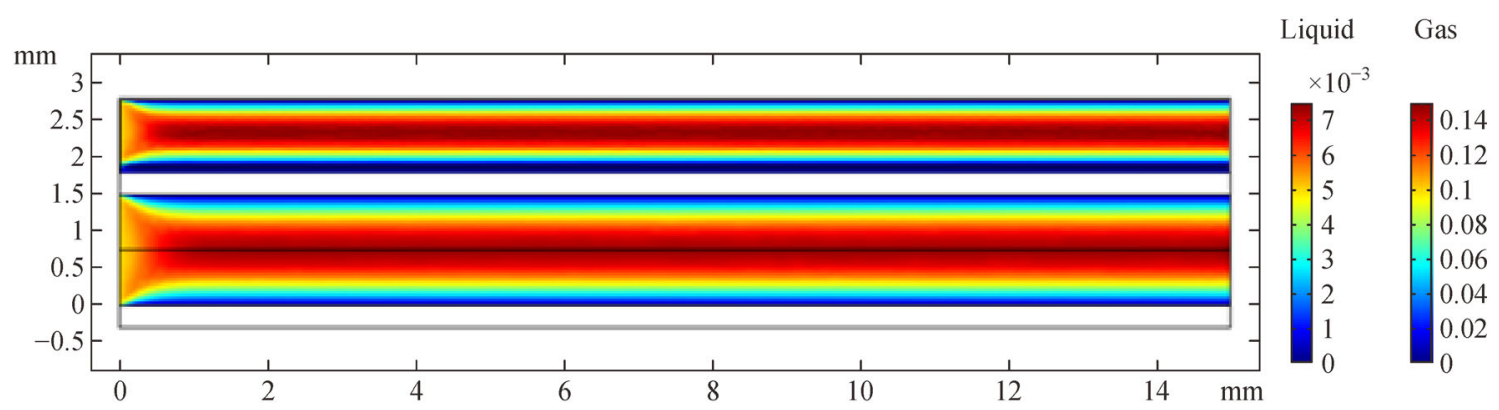

(a)

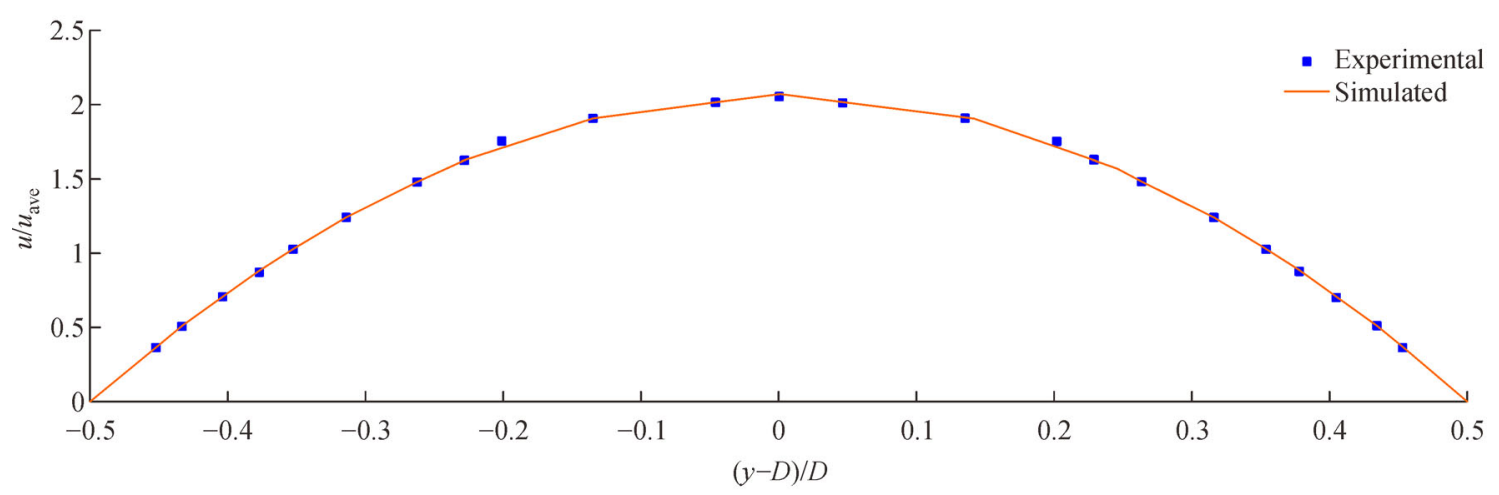

(b)

Fig. 2 (a) Velocity field of the gas and liquid ( $\mathrm{m} / \mathrm{s}$ ); (b) dimensionless velocity profile across channel height at $6 \mathrm{~mm}$ from the entrance, model results vs. experimental measurements [42]. 


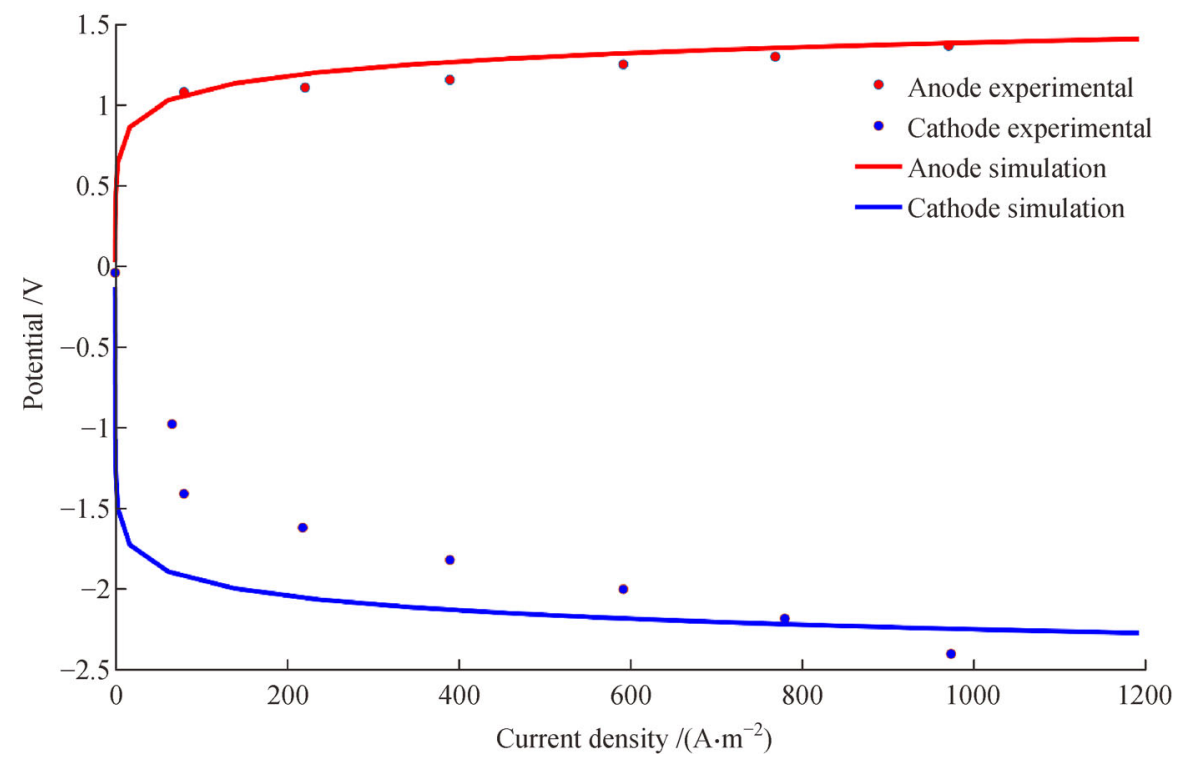

Fig. 3 Model results vs. experimental data for $\mathrm{pH}=10.0$ [43].

factor. Electrode diffusivity is specified as the limiting factor when neither the concentrations reach the threshold. To establish a valid benchmark for the reaction schemes, independent of the diffusion coefficient of the electrode, the porosity of the electrode was kept constant in all cases. As shown in Table 5, $\mathrm{CO}_{2}$ at the cathode is the limiting factor for most of the organic-based solvents. This underlines the efficiency of the cell for $\mathrm{CO}_{2}$ utilization in these cases where other factors of the cell can be improved to increase the cell efficiency.

Incorporating the discussed mass transfer results in choosing the highest performance configuration requires extra care as each reaction set will lead to a unique cell condition, solvent and catalyst determination. Cell performance design can be tailored from multiple points of view, depending on the industrial and economical requirements. Here, we study cell kinetic configuration according to energy and current efficiencies (section 3.2), environmental (section 3.3) and economical (section 3.4) aspects.

\subsection{Maximizing cell energy and current efficiencies}

Cell energy efficiency is calculated by:

$$
\eta_{\mathrm{e}}=\frac{\text { Energy content of the products }(\mathrm{kJ} / \mathrm{mol}) \times \text { cell fuel production }(\mathrm{mol} / \mathrm{s})}{V_{\text {cell }} I_{\text {cell }}(\mathrm{kJ} / \mathrm{s})},
$$

where $\eta_{\mathrm{e}}$ is the energy efficiency, $V_{\text {cell }}$ is the cell voltage and $I_{\text {cell }}$ is the electrical current consumed in the cell. As shown in Fig. 4(a), cell energy efficiency changes across a wide range depending on the reaction kinetics. Replacing the initial anodic half-cell mentioned in section 2.3 can result in up to $\sim 88.0 \%$ increase in cell energy efficiency. Another important factor that needs to be taken into consideration is cell current efficiency. This value demonstrates cell selectivity and is the current transferred to $\mathrm{CO}_{2}$ divided by the total current consumed in the cell:

$$
\eta_{i}=\frac{\text { Current transferred to the main reactant/product }}{\text { Current consumed in the cell }} \text {. }
$$

Figure 4(b) shows the current efficiency for various halfcell reactions. In general, higher current efficiency and hence, better cell selectivity is observed when organic solvents are used because of the lack of HER at the cathode. The reason behind higher current efficiencies in half-cell reactions 2 and 5 is that $\mathrm{CO}_{2}$ is assumed to be the main reactant in these cases, however, $\mathrm{CO}_{2}$ is also produced at the anode and hence the reactions show a higher current efficiency.

\subsection{Environmental aspects}

To get a step closer to completing $\mathrm{CO}_{2}$ industrial cycle, one of the main requirements of the proposed electrolytic cell is higher $\mathrm{CO}_{2}$ consumption rate in the proposed reaction scheme. $\mathrm{CO}_{2}$ consumption rate can be defined as:

$$
X_{\mathrm{CO}_{2}}=\frac{\mathrm{CO}_{2} \text { reacted }(\mathrm{mol} / \mathrm{s})}{\mathrm{CO}_{2} \text { fed }(\mathrm{mol} / \mathrm{s})} .
$$

Figure 5(a) shows the $\mathrm{CO}_{2}$ consumption rate. Using organic solvents result in higher overall $\mathrm{CO}_{2}$ removal rate, due to the lack of HER at the cathode (e.g., reactions 16- 
Table 4 Model input parameters

\begin{tabular}{|c|c|}
\hline Quantity/unit & Value \\
\hline$\overline{\text { Electrolyte conductivity } /\left(\mathrm{S} \cdot \mathrm{m}^{-1}\right)}$ & 0.4 \\
\hline Channel height $/ \mathrm{mm}$ & 1.5 \\
\hline Channel length $/ \mathrm{mm}$ & 15 \\
\hline Flow velocity $/\left(\mathrm{m} \cdot \mathrm{s}^{-1}\right)$ & 0.005 \\
\hline Electrolyte density $/\left(\mathrm{kg} \cdot \mathrm{m}^{-3}\right)$ & 1008 \\
\hline $\mathrm{CO}_{2}$ initial concentration $/\left(\mathrm{mol} \cdot \mathrm{L}^{-1}\right)$ & 0.001 \\
\hline Cathode equilibrium potential/V & -1.02 \\
\hline Cathode HER equilibrium potential $/ \mathrm{V}$ & -0.83 \\
\hline Anode equilibrium potential $/ \mathrm{V}$ & 0 \\
\hline Cathode exchange current density $/\left(\mathrm{A} \cdot \mathrm{m}^{-2}\right)$ & 0.1 \\
\hline Cathode HER exchange current density $/\left(\mathrm{A} \cdot \mathrm{m}^{-2}\right)$ & 0.016 \\
\hline Anode exchange current density $/\left(\mathrm{A} \cdot \mathrm{m}^{-2}\right)$ & 0.02 \\
\hline $\mathrm{OH}^{-}$initial concentration $/\left(\mathrm{mol} \cdot \mathrm{L}^{-1}\right)$ & $1 e-4$ \\
\hline Electrolyte flow rate $/\left(\mathrm{L} \cdot \mathrm{min}^{-1}\right)$ & $0.5 \mathrm{e}-3$ \\
\hline $\mathrm{V}$ polarization $/ \mathrm{V}$ & 1.5 \\
\hline Anode charge transfer coefficient & 0.16 \\
\hline Cathode charge transfer coefficient & -0.05 \\
\hline Cathode HER charge transfer coefficient & -0.5 \\
\hline Channel depth/cm & 0.5 \\
\hline Porous height $/ \mathrm{mm}$ & 0.3 \\
\hline Gas channel height/mm & 1 \\
\hline Electrode permeability $/ \mathrm{m}^{2}$ & $1 \mathrm{e}-12$ \\
\hline Electrode porosity & 0.7 \\
\hline Gas density $/\left(\mathrm{kg} \cdot \mathrm{m}^{-3}\right)$ & 1.562 \\
\hline Gas viscosity $/\left(\mathrm{kg} \cdot \mathrm{m}^{-1} \cdot \mathrm{s}^{-1}\right)$ & $1.48 \mathrm{e}-5$ \\
\hline
\end{tabular}

Table 5 Cell kinetics limiting factor according to the chosen cell kinetics scheme

\begin{tabular}{lc}
\hline Reaction number & Limiting factor \\
\hline $1,21,25,27$ & Electrode diffusivity \\
$2,3,4,5,6,7,8,9,10,11,12,13,14,15$ & Anodic reaction \\
$16,17,18,19,20,22,23,24$ & Cathodic reaction, $\mathrm{CO}_{2}$ \\
$26,28,29,30$ & Cathodic reaction \\
\hline
\end{tabular}

20). Some reactions produce $\mathrm{CO}_{2}$ which will result in negative values (e.g., reactions $3 \& 4$ ). This value can also become zero when using other materials at the cathode (e.g., reactions 25-30). Replacing the anodic reactions can result in up to $\sim 50 \%$ increase in $\mathrm{CO}_{2}$ removal rate compared to the initial cell reaction configuration discussed in section 2.3. Another important factor that needs to be accounted for during industrialization of the process is the amount of waste produced during the process. This can be quantified by calculating the E-factor of the process [44]:

$$
\text { E-factor }=\frac{\mathrm{kgs} \text { of waste produced }}{\mathrm{kgs} \text { of desired product }} .
$$

Figure 5(b) shows the E-factor of the cell according to various incorporated half-cell kinetics. The overall E-factor is high due to the design of the studied continues-flow reactor. A large amount of solvent and reactant is flushed in the system leaving a large environmental carbon footprint. This issue can be mitigated by optimizing the cell and recycling the solvent.

\subsection{Economic factor}

The overall economical added value during the process can be calculated as:

added value $(£ / \mathrm{mol})=$ value of products $(£ / \mathrm{mol})-$ value

$$
\text { of reactants }(£ / \mathrm{mol}) \text {. }
$$

As shown in Fig. 6, added value changes over a wide range and can reach up to $\sim 20000 £ / m o l$ if the product is purified to $99.9 \%$ or $\sim 1000 £ / \mathrm{mol}$ if the product is purified to $80 \%$. However, some reactions lead to negative added value which are not economic viable.

\subsection{Cell optimization and device engineering}

The cathodic overpotential is among the largest sources of inefficiencies in current $\mathrm{CO}_{2}$ electrolysers, followed by the anodic one [13]. Replacing the cathodic and anodic reactions can greatly improve cell performance by introducing new kinetics at each electrode. Various industrial scenarios can now be targeted with the proper reaction scheme identified based on the results discussed in section 3.2-3.4. Cell optimization can be performed by maximizing cell energy and current efficiencies, environmental aspects or economic factors.

From an efficiency point of view, anodic reaction 13 and cathodic reaction 22 were used as cell main kinetics (see Fig. 4). This is oxidizing glucose to gluconic acid at the anode while reducing $\mathrm{CO}_{2}$ to ethanol at the cathode. The overall cell energy efficiency was increased to $340 \%$ as both products have high free Gibbs energy content. Other cell performance factors include $\mathrm{CO}_{2}$ conversion rate of $69.3 \%$, current efficiency of $56.7 \%$ and E-factor of 704 . Another important performance factor can be optimized is the $\mathrm{CO}_{2}$ conversion rate (see Fig. 5). DMF is assumed to be the solvent as the HER is omitted at the cathode. Any of the cathodic reactions 16-20 can be used as they demonstrate similar $\mathrm{CO}_{2}$ conversion rate. In theory, it is possible to pick a water-based solvent at the anode and separate the two phases either by a proton exchange membrane or rely on the natural phase separation as the two phases become immiscible in the given cell dimensions. Reaction number 24 is chosen at the anode where $\mathrm{CO}_{2}$ is reduced to $\mathrm{CO}$. 

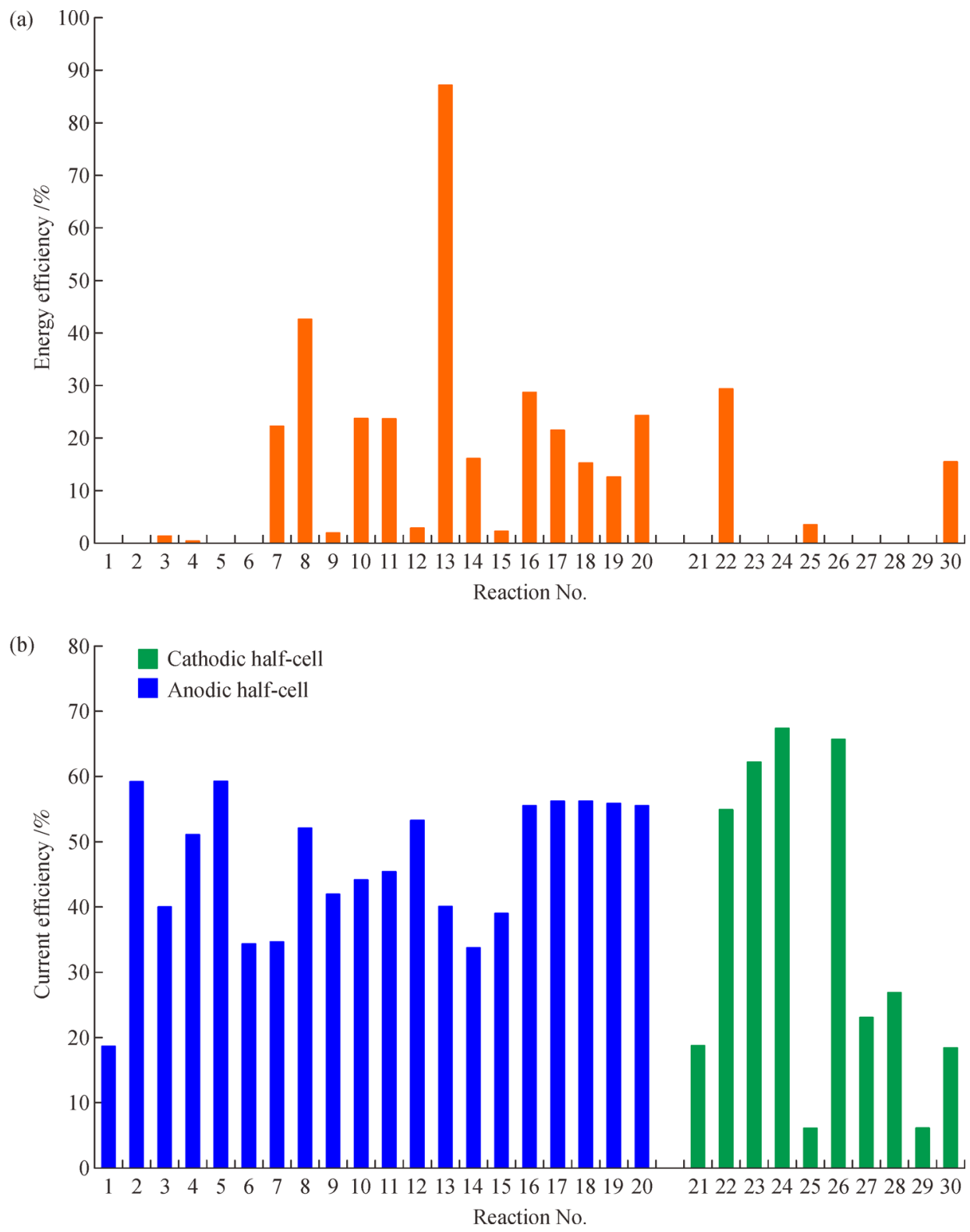

Fig. 4 (a) Energy efficiency and (b) current efficiency for various half-cell reactions.

Under these conditions the theoretical $\mathrm{CO}_{2}$ conversion rate reaches $\sim 90 \%$ as the reaction is limited by the $\mathrm{CO}_{2}$ diffusibility rather than cell kinetics. From an economical point of view, the added value of the product is not affected by altering the cathodic reaction. The results shown in Fig. 6 can be used to estimate the cell overall added value for various cell kinetics.

An indication of the cell performing at its optimized state is maximizing the current density across the electrodes in the direction of flow. Current density rises sharply at the cell entrance due to availability of the reactants. Moving in the stream direction, products begin to accumulate across the electrode surface, creating a resistive layer which occupies the catalyst active sites and slows down the electrode reaction. Due to extremely laminar flow throughout the system, the dominant mass transfer mechanism along the channel width and height is diffusion, which drives the resistive layer formation. The resistive layer formation rate depends on the reaction kinetics, reactant and product diffusivity in the solvent and stream velocity.

For the case study mentioned earlier where the cell efficiency is maximized, the reactor length was calculated $\sim 120 \mathrm{~mm}$ for $90 \% \mathrm{CO}_{2}$ conversion rate. This length was chosen because from this point, increasing the channel length does not increase the energy efficiency significantly as shown in Fig. 7(a). To determine other design parameters, energy conversion rate was considered as free Gibbs energy of the products divided by the energy consumed in the continuous flow reactor. Please note that 

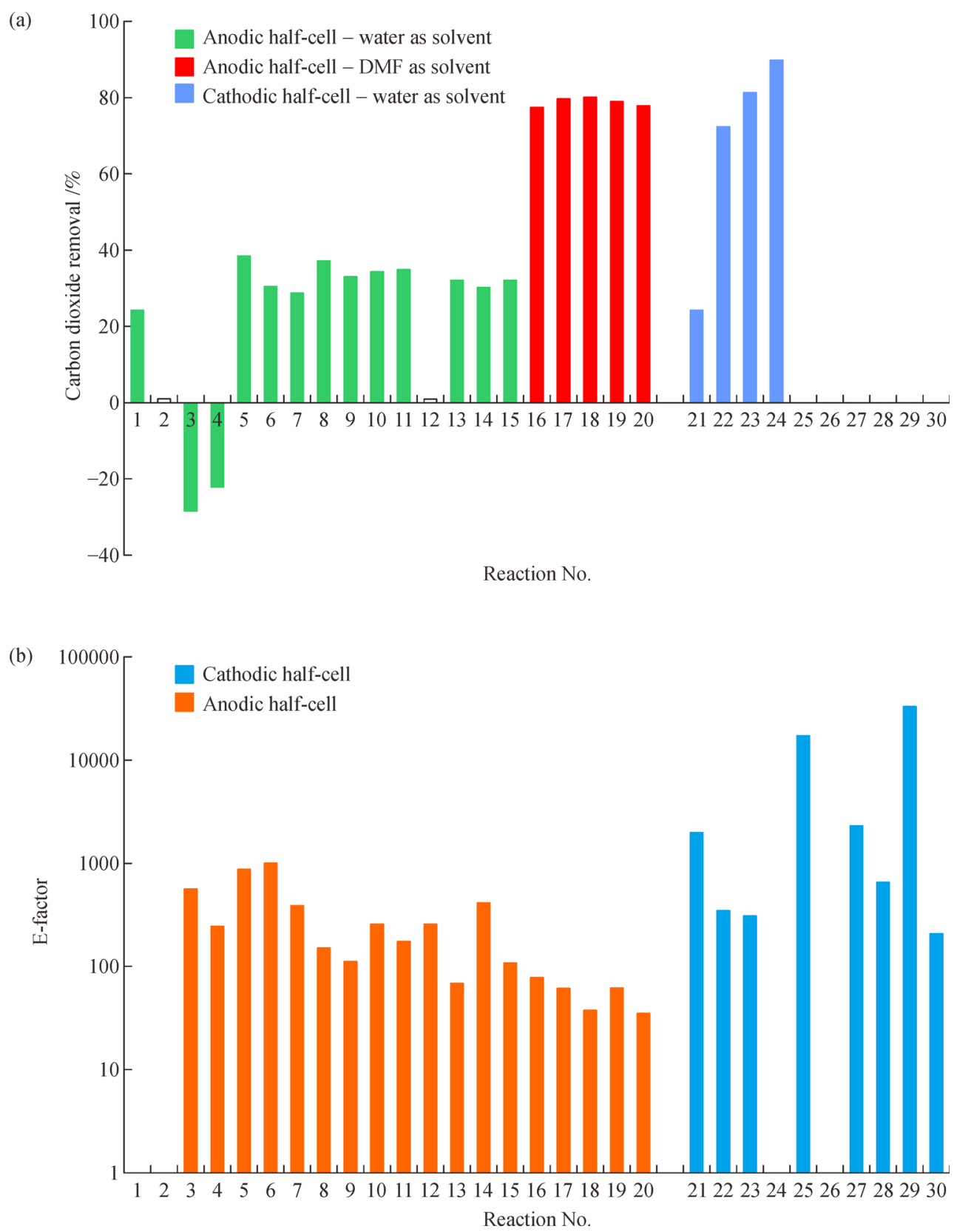

Fig. 5 (a) $\mathrm{CO}_{2}$ removal rate and (b) E-factor for various half-cell reactions.

this parameter can be greater than $100 \%$, as the energy content of the final products may be higher than the energy used during the process. Other design parameters were determined from Figs. 7(b and c) as follows: Electrolyte flowrate $0.65 \mathrm{~L} / \mathrm{min}, \mathrm{CO}_{2}$ inlet flowrate $4.5 \mathrm{SCCM}$ and channel height $1.7 \mathrm{~mm}$.

\section{Conclusions}

A continuous electrolytic cell was computationally modelled and verified. The model was then used with various cell kinetics to determine the most optimized cell configuration in different scenarios for the e-biofuel processes. The kinetics studied were chosen from a range of organic compounds where at least one reaction from each group (carboxylic acids, alcohols, aldehydes, etc.) was presented. Latest progresses in $\mathrm{CO}_{2}$ electroreduction kinetics and biomass oxidation for fuel production was included in this study as well.

Using non-water solvent in general improves the cell efficiency as HER is omitted at the cathode. While the energy efficiency of the cell is mostly dictated by the energy content of the main products, the $\mathrm{CO}_{2}$ conversion rate can be greatly improved by cleverly choosing the reactor kinetics. The overall environmental impact 


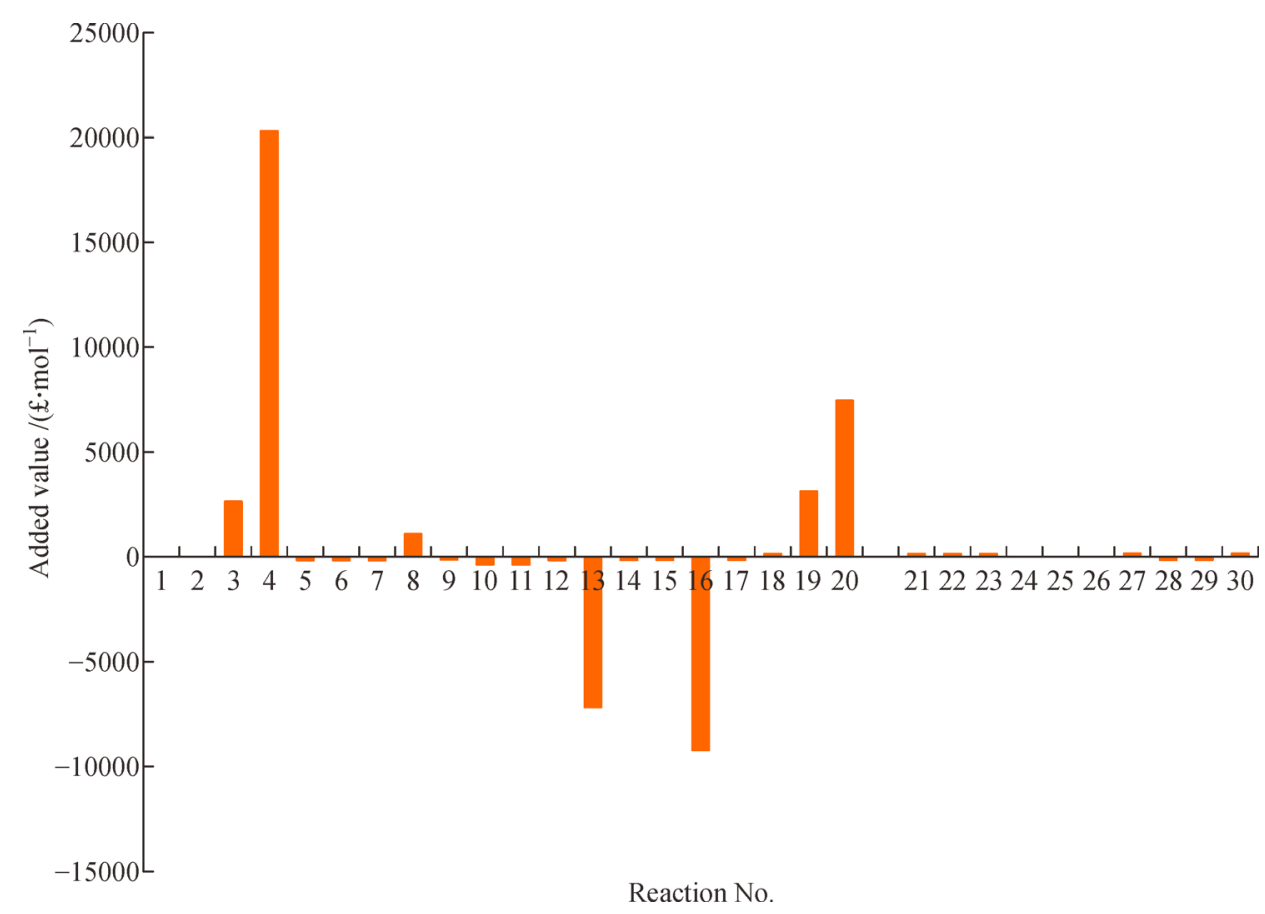

Fig. 6 Product added value.

(a)

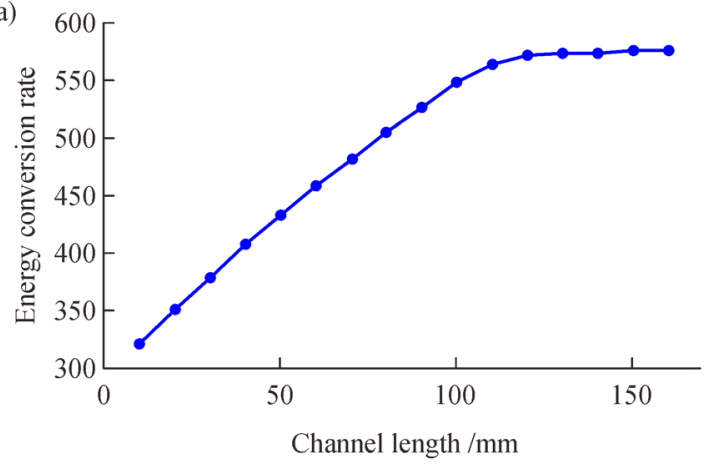

(c)

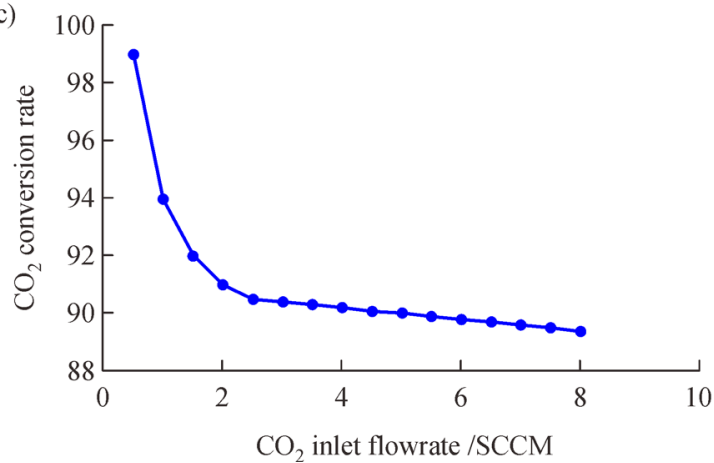

(b)

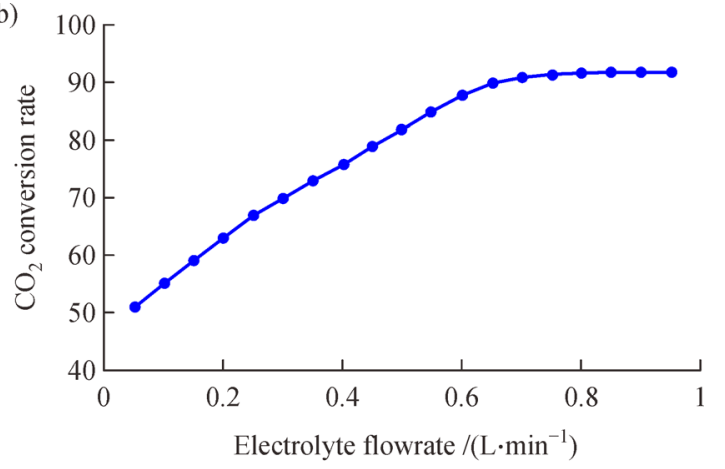

(d)

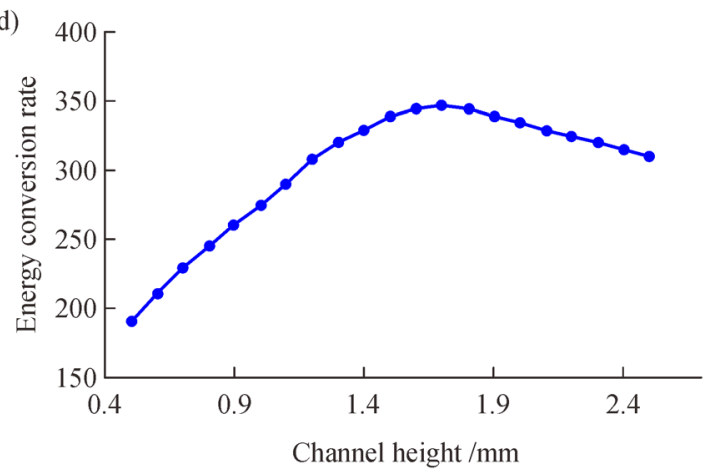

Fig. 7 Cell design optimization parameters. (a) Channel length vs. energy conversion rate, (b) electrolyte flowrate vs. $\mathrm{CO}_{2}$ conversion rate, (c) $\mathrm{CO}_{2}$ inlet flowrate vs. $\mathrm{CO}_{2}$ conversion rate and (d) channel height vs. energy conversion rate.

(E-factor) is high compared to other industrial processes. This is due to the high volume of the solvent compared to the product and can potentially be mitigated by re- circulating the solvent in the system. The economic added value of the cell is mostly determined by the products at the anode for the selected reaction scheme. 
The guidelines provided in this study can be used to design economically and industrially viable continuous flow electrolytic cells and pave the way for future carbon utilization setups.

Acknowledgements This work is jointly supported by the UK Supergen Bioenergy Hub and the Department for Transport via grant number SGBH FF Feb2019 1.

Open Access This article is licensed under a Creative Commons Attribution 4.0 International License, which permits use, sharing, adaptation, distribution and reproduction in any medium or format, as long as you give appropriate credit to the original author(s) and the source, provide a link to the Creative Commons licence, and indicate if changes were made. The images or other third party material in this article are included in the article's Creative Commons licence, unless indicated otherwise in a credit line to the material. If material is not included in the article's Creative Commons licence and your intended use is not permitted by statutory regulation or exceeds the permitted use, you will need to obtain permission directly from the copyright holder. To view a copy of this licence, visit http://creativecommons.org/licenses/by/4.0/.

\section{References}

1. Zsiborács H, Baranyai N H, Vincze A, Zentkó L, Birkner Z, Máté K, Pintér G. Intermittent renewable energy sources: The role of energy storage in the European power system of 2040. Electronics (Basel), 2019, 8(7): 729

2. Dadhich P, Dooley J, Fujii Y, Hohmeyer O, Riahi K. Cost and economic potential. IPCC Special Report on Carbon Dioxide Capture Storage, 2005: 341-362

3. Pérez-Fortes M, Schöneberger J C, Boulamanti A, Harrison G, Tzimas E. Formic acid synthesis using $\mathrm{CO}_{2}$ as raw material: Technoeconomic and environmental evaluation and market potential. International Journal of Hydrogen Energy, 2016, 41(37): 16444 16462

4. Verma S, Lu S, Kenis P J A. Co-electrolysis of $\mathrm{CO}_{2}$ and glycerol as a pathway to carbon chemicals with improved technoeconomics due to low electricity consumption. Nature Energy, 2019, 4(6): 466-474

5. Das S, Balaraju T, Barman S, Sreejith S S, Pochamoni R, Roy S. A molecular $\mathrm{CO}_{2}$ reduction catalyst based on giant polyoxometalate Mo368. Frontiers in Chemistry, 2018, 6: 514

6. Liu Z, Yang H, Kutz R, Masel R I. $\mathrm{CO}_{2}$ electrolysis to $\mathrm{CO}$ and $\mathrm{O}_{2}$ at high selectivity, stability and efficiency using sustainion membranes. Journal of the Electrochemical Society, 2018, 165(15): J3371-J3377

7. Kaczur J J, Yang H, Liu Z, Sajjad S D, Masel R I. Carbon dioxide and water electrolysis using new alkaline stable anion membranes. Frontiers in Chemistry, 2018, 6: 1-16

8. Lu J, Zhu C, Pan C, Lin W, Lemmon J P, Chen F, Li C, Xie K. Highly efficient electrochemical reforming of $\mathrm{CH}_{4} / \mathrm{CO}_{2}$ in a solid oxide electrolyser. Science Advances, 2018, 4(3): eaar5100

9. Li Y C, Lee G, Yuan T, Wang Y, Nam D H, Wang Z, García de Arquer F P, Lum Y, Dinh C T, Voznyy O, Sargent E H. $\mathrm{CO}_{2}$ electroreduction from carbonate electrolyte. ACS Energy Letters, 2019, 4(6): 1427-1431

10. Wang L, Chen M, Küngas R, Lin T E, Diethelm S, Maréchal F, Van herle J. Power-to-fuels via solid-oxide electrolyzer: Operating window and techno-economics. Renewable \& Sustainable Energy Reviews, 2019, 110: 174-187

11. Wang L, Pérez-Fortes M, Madi H, Diethelm S, herle J V, Maréchal F. Optimal design of solid-oxide electrolyzer based power-tomethane systems: A comprehensive comparison between steam electrolysis and co-electrolysis. Applied Energy, 2018, 211: 10601079

12. Tatin A, Comminges C, Kokoh B, Costentin C, Robert M, Savéant J M. Efficient electrolyzer for $\mathrm{CO}_{2}$ splitting in neutral water using earth-abundant materials. Proceeding of the National Academy of Science of the United States of America, 2016, 113 (20): 5526-5529

13. Larrazábal G O, Martín A J, Pérez-Ramírez J. Building blocks for high performance in electrocatalytic $\mathrm{CO}_{2}$ reduction: Materials, optimization strategies, and device engineering. Journal of Physical Chemistry Letters, 2017, 8(16): 3933-3944

14. Lukaszewski M, Soszko M, Czerwiński A. Electrochemical methods of real surface area determination of noble metal electrodes - an overview. International Journal of Electrochemical Science, 2016, 11(6): 4442-4469

15. Li X, Angelidaki I, Zhang Y. Salinity-gradient energy driven microbial electrosynthesis of value-added chemicals from $\mathrm{CO}_{2}$ reduction. Water Research, 2018, 142: 396-404

16. Conway B E, Dzieciuch M. New approaches to the Study of electrochemical decarboxylation and the Kolbe reaction: Part I. The model reaction with formate. Canadian Journal of Chemistry, 2011, 41(1): 21-37

17. Bockris J O. Modern Aspects of Electrochemistry. No. 4, 1st ed. Berlin: Springer, 1966, 1-46

18. Hicks M T, Fedkiw P S. A model for Kolbe electrolysis in a parallel plate reactor. Journal of Applied Electrochemistry, 1998, 28(11): $1157-1166$

19. Li Y, Khanal S K. Bioenergy: Principles and Applications. 1st ed. Hoboken: Wiley-Blackwell, 2016, 1-600

20. Verma S, Lu S, Kenis P J A. Co-electrolysis of $\mathrm{CO}_{2}$ and glycerol as a pathway to carbon chemicals with improved technoeconomics due to low electricity consumption. Nature Energy, 2019, 4(6): 466-474

21. Li T, Cao Y, He J, Berlinguette C P. Electrolytic $\mathrm{CO}_{2}$ reduction in tandem with oxidative organic chemistry. ACS Central Science, 2017, 3(7): 778-783

22. Latsuzbaia R, Bisselink R, Anastasopol A, van der Meer H, van Heck R, Segurola Yagüe M, Zijlstra M, Roelands M, Crockatt M, Goetheer E, et al. Continuous electrochemical oxidation of biomass derived 5- (hydroxymethyl) furfural into 2,5-furandicarboxylic acid. Journal of Applied Electrochemistry, 2018, 48(6): 611-626

23. Kubota S R, Choi K. Electrochemical oxidation of 5-hydroxymethylfurfural to 2,5-furandicarboxylic acid (FDCA) in acidic media enabling spontaneous FDCA separation. ChemSusChem, 2018, 11(13): 2138-2145

24. Liu W, Dang L, Xu Z, Yu H, Jin S, Huber G W. Electrochemical oxidation of 5-hydroxymethylfurfural with $\mathrm{NiFe}$ layered double hydroxide (LDH) nanosheet catalysts. ACS Catalysis, 2018, 8(6): 5533-5541

25. Hampson N A, Lee J B, MacDonald K I. The oxidation of amino compounds at anodic silver. Electrochimica Acta, 1972, 17(5): 921955

26. Fuchigami T, Atobe M, Inagi S. Examples of Organic Electro- 
synthesis. Fundamentals and Applications of Organic Electrochemistry. 1st ed. Hoboken: John Wiley \& Sons Ltd., 2014, 209-216

27. Krumgalz B S, Barthel J G M. Conductivity study of electrolyte solutions in dimethylformamide at various temperatures. Zeitschrift für Physikalische Chemie (Leipzig), 1984, 142(2): 167-178

28. Yaws C L. The Yaws Handbook of Physical Properties for Hydrocarbons and Chemicals. 2nd ed. Oxford: Gulf Professional Publishing, 2015, 10-812

29. Shono T, Matsumura Y, Tsubata K. Anodic oxidation of $N$-carbomethoxypyrrolidine: 2-methoxy- $N$-carbomethoxypyrrolidine. Organic Syntheses. 1st ed. Hoboken: John Wiley \& Sons Inc., 2003

30. Fritz H P. Electrochemical anodic of naphtaline and 1 and 2-methoxynaphtaline. Electrochimica Acta, 1976, 2: 1099-1100

31. Shono T, Ikeda A. Electroorganic Chemistry. Journal of the American Chemical Society, 1972, 94(22): 7892-7898

32. Gallardo I, Guirado G, Marquet J. Nucleophilic. Aromatic substitution of hydrogen: A novel electrochemical approach to the cyanation of nitroarenes. ChemInform, 2010, 33(13): 1759-1765

33. Rumble J. CRC Handbook of Chemistry and Physics. 95th ed. Boca Raton: CRC Press, 2014, 1118-1512

34. Pang S C, Chin S F, Anderson M A. Redox equilibria of iron oxides in aqueous-based magnetite dispersions: Effect of $\mathrm{pH}$ and redox potential. Journal of Colloid and Interface Science, 2007, 311(1): 94-101

35. COMSOL Multiphysics ${ }^{\circledR}, v$ 5.4. Stockholm: COMSOL AB, 2019
36. Wang H, Leung D Y C, Xuan J. Modeling of a microfluidic electrochemical cell for $\mathrm{CO}_{2}$ utilization and fuel production. Applied Energy, 2013, 102: 1057-1062

37. Rosenqvist $\mathrm{T}$, Haugom J. Gibbs energy of formation of $\mathrm{SO}_{2}$. Journal of the Chemical Society, Faraday Transaction 1. Physical Chemistry in Condensed Phases, 1976, 21(12): 1649-1654

38. Baker D. General Chemistry. 5th ed. (Ebbing, Darrell D.). Journal of Chemical Education, 1997, 74(9):1049

39. Faria R P V, Pereira C S M, Silva V M T M, Loureiro J M, Rodrigues A E. Glycerol valorization as biofuel: Thermodynamic and kinetic study of the acetalization of glycerol with acetaldehyde. Industrial \& Engineering Chemistry Research, 2013, 52(4): 15381547

40. Stephanopoulos G N, Aristidou A A, Nielsen J. Thermodynamics of Cellular Processes. 1st ed. Amsterdam: Elsevier, 1998, 629-694

41. Ahmad Z. Principles of Corrosion Engineering and Corrosion Control. 1st ed. Amsterdam: Elsevier, 2006, 217-218

42. Goldstein R J, Kreid D K. Measurement of laminar flow development in a square duct using a laser-doppler flowmeter. Journal of Applied Mechanics, Transactions ASME, 1964, 34(4): 813-818

43. Whipple D T, Finke E C, Kenis P J A. Microfluidic reactor for the electrochemical reduction of carbon dioxide: The effect of $\mathrm{pH}$. Electrochemical and Solid-State Letters, 2010, 13(9): B109

44. Sheldon R A. The E-factor: Fifteen years on. Green Chemistry, 2007, 9(12): 1273-1283 